\title{
Lower Secondary School Pupils' Perception of e-Textbooks
}

\author{
Josef Moravec, Karolína Pešková
}

\begin{abstract}
The presented study aims to build on pupils' perception of textbooks in respect to the kind of textbook (printed or electronic) pupils prefer to use at school. The main research aim of the study was to investigate pupils' perception of the (future) use of e-textbooks as pupils are the population who are the textbooks primarily intended for. The partial aim was to find out advantages and disadvantages of printed textbooks and e-textbooks from the pupils' point of view. A questionnaire with demographic and context focused items, 5-point scale Likert type items and open-ended items was chosen as a research tool. The sample included 250 lower secondary school pupils from the Czech Republic. To analyse the data, methods of descriptive and inferential statistics were used. The results of the study showed that no matter if pupils use e-textbooks, the majority of respondents would like to use the e-textbooks in the future. In addition, according to the study pupils have more positive perception of the e-textbook than the printed textbook.
\end{abstract}

Keywords: E-textbook, lower secondary school pupils, perception, printed textbook.

The presented investigation aims to build on pupils' needs in respect to the learning materials they prefer to use at school and at home. More specifically, the research attention is paid to textbooks - traditional printed and electronic textbooks (e-textbooks). Since there is a huge expansion of ICT use in education, the question of the future of printed textbooks is essential (Terpend, Gattiker \& Lowe, 2014; Heejeong \& Kok-Lim, 2015). 
After discussing appropriate definitions of e-textbook the authors of this study deal with a brief theoretical introduction to the issue of learning with e-textbooks. Further on with reference to the gap in the related research area, the authors investigate pupils' perception of the (future) use of e-textbooks and present results of a pilot questionnaire study.

\section{Definition of e-textbook}

The term e-textbook (electronic textbook) is in this study considered subordinated to the term e-book (electronic book). Therefore, at first the term e-book is discussed. Although e-textbooks have been available for several years, the terminology and definition of this technology are still disputed (Bennett, 2006). Some older studies are also taken into account in this study because of their steady relevance in the present. According to the study of Vassiliou \& Rowley (2008) 37 different definitions of the term e-book were found. The reason of this disunity might be fast development of technologies and devices which enable to read the e-book (Martinez-Estrada \& Conaway, 2012). Every device (PC, notebook, tablet, smartphone or another electronic device) enriches the e-book with other elements which affect the way of work with the e-book and different designation of the e-book. In order to clarify the disunited terminology of this issue, first of all the definition of e-book and then definition of e-textbook and its kinds are presented in this chapter.

In a broader context, e-book can be defined as a text converted to an electronic (Hawkins, 2000; McKnight \& Dearnley, 2003) or alternatively a digital form (Reitz, 2004; Gardiner \& Musto, 2010). It is an electronic equivalent of a printed book (Gay, 2007). It is made available electronically (or optically) for any device (handheld or desk-bound) that includes a screen (Armstrong et al., 2002). In comparison with the printed book, the e-book consists of some in-use features (search functions, highlights, hypertext links etc.) which are specific only for an electronic environment (Vassiliou \& Rowley, 2008). More precisely in the school context, the e-book can be termed as e-textbook, which is an instructional text in an electronic (digital) form (Cutshall, Mollick, \& Bland, 2009; Landoni \& Diaz, 2006; Simon, 2001).

According to the content and device which is possible to read the e-textbook on, several kinds of the e-textbook can be named. If the e-textbook consists of multimedia components (text, animation, audio, video), it is possible to name it as multimedia textbook (Bradshaw, 2005). If it incorporates interactive components (reacting on the human touch), it can be named as interactive textbook (Miller \& Ranum, 2012; Mitropoulou, 2012). But it is necessary to differentiate between interactive textbooks for the use of interactive white boards and for tablets or another electronic device because 
this differentiation reflects the options of tools which are possible to use during the work with the textbook.

As it is obvious from above, the terminology of the e-textbook has been changing and there is no universally accepted definition. However, most authors choose only one term to use in their study and they do not present its definition (see e.g. Bryant \& Mims, 2012; Nicholas \& Lewis, 2010; Woody, Daniel, \& Baker, 2010). For the purpose of this study, only the term e-textbook is used and considered superordinate to its other forms (multimedia and interactive textbook). In the next chapter greater focus is put on the e-textbook in the learning context by taking into consideration its advantages and disadvantages.

\section{E-textbook in the context of learning}

There is no doubt that one of the main roles of the e-textbook at school is its contribution to pupils' motivation to learn (see e. g. Jones \& Brown, 2011). Besides, according to theoretical and empirical studies the e-textbook has many other advantages. For example, according to Bradshaw (2005) it employs a style well-suited to learner's needs, and works in the opportunity to practice and elaborate upon what students have learned. Cavanaugh (2002) stresses the advantage of the e-textbook for teaching special needs pupils and exceptional pupils who need more challenging information than a printed textbook can provide. One of the most frequently named advantages of the e-textbook is the relationship between its specific hardware and software parameters for reading and displaying e-textbooks (Beer \& Wagner, 2011; Vassiliou \& Rowley, 2008) which provides other opportunities to support cognitive processes of pupils than the printed textbook can do. So learners may interact with the content of e-textbooks more actively than just reading them (Nelson, 2008). For example, 3D animations presented in the e-textbook can serve pupils as a means of dealing with normally invisible structures and phenomena, such as a structure of an atom (Wang, Chang, \& Li, 2007). What is more, concerning affective processes Niegemann et al. (2008) mentions that audios can contribute to the authenticity of the instructional material and so enable to raise pupils' emotions. Last but not least advantage is that a learner can be collaboratively involved in activities based on the e-textbook (see the concept of Computer-Supported Collaborative Learning, Zurita \& Nussbaum, 2007).

Disadvantages of e-textbooks must be mentioned as well. One of the few authors who present disadvantages connected with components of e-textbooks is Mangen (2008). For example, concerning the already mentioned 3D animation he points out that this animation detracts from fantasy development and disables to produce own mental maps. Regarding hypertexts e. g. Arnold et al. (2013) draw attention to the danger of cognitive load (see Mayer, 2009), as the pupil can be overloaded while concentrating 
and searching for information, which causes failing of deeper information processing. In contrast to the cognitive theory of multimedia learning (see Mayer, 2005), some authors (e.g. Paas, Renkl, \& Sweller, 2004; Sweller, Ayres, \& Kalyuga, 2011) even argue that the use of multiple representations (in this case different e-textbooks components) can negatively affect learning. This can occur when pupils are exposed to multiple sources of information that are self-contained and can be used without reference to each other (redundancy effect) or when pupils have to mentally integrate relevant sources of physically separated information (split-attention effect; Liu, Lin, \& Paas, 2013).

From the above introduced brief outline of strong and weak sides of learning with e-textbooks a question of acceptance of e-textbooks by their users may emerge. When discussing the context of electronic environment, the Technology Acceptance Model (TAM) which has captured the most attention of the Information System Community (Chuttur, 2009) ought to be mentioned. It answers the question how users accept new technologies, how they use them and what factors influence users while deciding when and how to use these technologies (Benbasat $\&$ Barki, 2007). Despite the fact that much attention has been paid to the TAM in many studies (see e. g. Park, 2009; Shroff, Deneen, \& Ng, 2011, Yousafzai, Foxall \& Pallister, 2007), the model has also faced strong criticism concerning its application and theoretical accuracy (Chuttur, 2009). For this reason, in this study the TAM is found a fundamental piece of the theoretical background, but its application is being considered for the next research phase. In the following chapter attention is paid to the acceptance and perception of e-textbooks by having a deeper look at some present empirical findings.

\section{Review of literature}

The review of literature shows that the use of e-textbooks has been a widely researched issue in the last years. However, it is possible to consider perception of e-textbook from the pupils' point of view still insufficiently empirically investigated. Studies investigating the effect of learning with e-textbooks seem as more frequent. The most commonly used research tool in mentioned studies is a questionnaire.

Several studies confirm little to high significant difference in pupils/students' performance in favour of learning with e-textbooks compared to printed textbooks (e.g. Maynard \& Cheyne, 2005; McFall, Dershem, \& Davis, 2006; Staehr \& Byrne, 2011). For example, Maynard and Cheyne (2005) explored the potential e-textbooks have to enhance learning of children in History lessons. The study included 60 pupils, split into five groups of 12 participants ( 6 boys and 6 girls), which were afterwards split into two sub-groups of six ( 3 boys and 3 girls) so that one sub-group used the printed textbook, while the other used an e-textbook. The observation and questioning of pupils revealed 
that the e-textbook was widely accepted (according to pupils it made History easier and more fun) and motivated group participation.

Regarding the acceptance of e-textbooks, many studies focusing on university students can be referred to (e. g. Bryant \& Mims, 2012; Falc, 2013; Sun, Flores \& Tanguma, 2012). As an example, the study of Bryant and Mims (2012) can be named. Their study showed that students considered e-textbooks more current and timely than their print counterparts. On the contrary, according to Walton (2007, in Nelson, 2008) American college students expressed little to no preference for e-textbooks. A study by Elias et al. (2012) indicated that printed textbooks were preferred over e-textbooks. When asked if print or electronic texts were preferred, $84 \%$ of teachers and $78.7 \%$ of students responded that they preferred printed texts. $40 \%$ of teachers agreed that if their texts were available electronically, they would take them to class, with approximately $56 \%$ of students either agreeing or strongly agreeing with that statement.

Woody et al. (2010) carried out a questionnaire study of factors influencing preference for e-textbooks as well as reported use of e-textbook content. $59.3 \%$ of participants (university students) had decided to use an available e-textbook in a previous course. No significant correlations existed between the number of e-textbooks previously used and overall preference of e-books. Gender did not predict e-textbook use. Gender and e-textbook were not significantly associated.

Researchers Noor et al. (2012) investigated the presence and preference of e-textbooks in the lower secondary school classrooms. It was discovered that a majority of these pupils liked using the e-textbook. But only $16 \%$ used the e-textbook on a daily basis. The majority (65\%) used the e-textbook sometimes, while $19 \%$ rarely. More than half the pupils used the e-textbook to study at home ( $55 \%$ ). About $75 \%$ reported that they were able to follow lessons taught in the classroom using the e-textbook. When asked if they wanted to use the e-textbook during school hours, only $41 \%$ were willing while $32 \%$ were not. Concerning their preference between e-textbooks and textbooks, $43 \%$ preferred the e-textbook.

Oliveira et al. (2013) explored the perceptions of the use of e-textbooks in a primary school classroom held by a teacher and his pupils who do not use printed textbooks $(n=14)$. The study examined pupils' meaning-making practices and the views that teachers and students have on engagement in learning activities in this context. Data were collected by means of video recording, class observational notes, in-depth focus group interviews and an e-textbook online platform. All students stated they liked the e-textbook and they preferred using it to traditional textbooks. However, they also found the information presented in the e-textbook insufficient. Easiness to do activities and to find information, the possibility to see images and videos, and the novelty of e-textbooks were considered positive aspects of e-textbooks highlighted by the pupils.

When reviewing literature it is obvious that there is little evidence on the perception or acceptance of e-textbooks among lower secondary school pupils. According 
to a questionnaire study focusing on the use of textbooks conducted in Slovakia, one fourth of 15-year-old respondents prefer e-textbooks (Nogova, 2009). Nevertheless, similar studies carried out in the Czech Republic are missing.

\section{Purpose of the study}

The study tends to react on the situation of missing investigations into the acceptance of e-textbooks by lower secondary school pupils (in the Czech Republic). As the present Czech textbook market offers plenty of e-textbook titles mostly intended for lower secondary school pupils (the offer for upper secondary school and university students is limited), research in this sample is necessary. Pupils are the population who are the textbooks primarily intended for, so the following research aim was formulated: to investigate pupils' perception of the printed and e-textbooks. This aim is specified by three research questions: 1. To what extent do pupils' prefer e-textbooks to printed textbooks? 2. What advantages and disadvantages do e-textbooks and printed textbooks have from pupils' point of view? 3. Is there a difference in the perception of printed textbooks and e-textbooks by pupils using only printed textbooks and pupils using both printed and etextbooks? Based on the last question the following null hypotheses were formulated:

$\mathrm{H}_{01}$ : There is no statistically significant difference in the perception of the use of e-textbooks by pupils using only printed textbooks and pupils using both printed and e-textbooks.

$\mathrm{H}_{02}$ : There is no statistically significant difference in the perception of the use of printed textbooks by pupils using only printed textbooks and pupils using both printed and e-textbooks.

$\mathrm{H}_{03}$ : There is no statistically significant difference in the perception of the use of e-textbooks and the use of printed textbooks by pupils using only printed textbooks. $\mathrm{H}_{04}$ : There is no statistically significant difference in the perception of the use of e-textbooks and the use of printed textbooks by pupils using printed textbooks and e-textbooks.

The presented investigation is a pilot study of research focused on pupils' perception of e-textbooks. This study was conducted to undertake the first step to investigate pupils' perception of learning with e-textbooks. Therefore, it approaches the issue at a rather superficial level to find out if pupils perceive e-textbooks positively at all. Then in the next step, the focus will be laid on deeper understanding of learning with e-textbooks from the pupils' point of view, especially in relation to pupils' motivation to learn as a factor which may impact learning with e-textbooks in the future. 


\section{Methodology}

To fulfil the research aim and answer the research questions the following methodology based on a questionnaire as a research tool was used.

\section{Research tool}

As a research tool a questionnaire with following types of items was used: First 10, mainly dichotomous and polytomous, were demographic and context focused items (referring to gender, age, grade, use of PC, use of the Internet, favour of the IT subject, use of the e-textbook at school, use of the e-textbook at home, use of other electronic learning aids). 4 open-ended questions (referring to advantages and disadvantages of printed and e-textbooks) were included in order to gain free opinions of pupils independently on their statements to Likert type items. Following 10 Likert type items with a 5-point scale (agree - slightly agree - nor agree/nor disagree - slightly disagree - disagree) were focused on advantages and disadvantages of the use of printed textbooks and e-textbooks and pupils' preferences for printed textbooks/e-textbooks. They included 7 positive items focused on e-textbooks (e.g. I would like to use the e-textbook as the main learning aid) and 3 negative items focused on advantages of printed textbooks (e.g. Learning with the printed textbook suits me). The questionnaire was administrated among pupils who use and do not use e-textbooks. For the pupils who do not use e-textbooks at school and at home, the wording of items referring to the use of e-textbooks was slightly modified (transformed into conditional sentences). A definition of e-textbook was provided at the beginning of both questionnaire versions.

\section{Sample}

The study included 250 lower secondary school pupils (127 girls, 123 boys coming from 7 different schools) from the Czech Republic using e-textbooks or/and printed textbooks (across different subjects). The pupils were 12-16 years old, which corresponds with the $7^{\text {th }}-9^{\text {th }}$ grade. Most of the pupils came from the $9^{\text {th }}$ grade $(63 \%)$ and were 15 years old (54\%). Schools were from the South Moravian Region, the city of Brno in the Czech Republic. The schools were selected by means of convenience sampling.

\section{Data Collection}

The author of the research tools for pupil's questionnaire handed them personally in paper form. Before completing the questionnaire, students were informed about the research topic. For students who had not had the opportunity to work with an electronic 
textbook, this type of textbook was described before executing the questionnaire. Students filled out a questionnaire with a pen. Upon completion of all questionnaires in class, questionnaires were personally collected and switched to data analysis.

\section{Data analysis}

First collected data were coded into a numeral form. The expressed degree of agreement-disagreement of pupils was coded in descending order with 5-1 points in positive items and reversed in ascending order with 1-5 points in negative items (coded in an opposite way). To analyse the data methods of quantitative and qualitative research were used. Methods of descriptive statistics were used to analyse the demographic, context focused and Likert type items (mean score, standard deviation). Proportional representation (percent frequency) of statements to single items was also computed. According to the obtained scores of statements to Likert type items it was stated whether pupils' perception of printed textbooks and e-textbooks is negative, neutral or positive (negative perception was considered when the score was 1-2.75, neutral 2.75-3.25 and positive 3.25-5). The t-test for independent samples was used to investigate the statistical difference of views of pupils divided into the following groups: (1) views of pupils using printed textbooks on printed textbooks, (2) views of pupils using e-textbooks on printed textbooks, (3) views of pupils using printed textbooks on e-textbooks, (4) views of pupils using e-textbooks on e-textbooks.

To analyse the open-ended items, the procedure of open coding was used. First the hand written answers of pupils were transcribed into an electronic form and coded by one researcher (by using the pencil and paper method). In the next phase, the most frequently occurred codes were recorded and transformed into more abstract categories. Three main categories referring to the advantages and disadvantages of printed textbooks and e-textbooks occurred: issues of technical background, issues of learning background and issues of health background. The whole procedure was revised by another researcher.

\section{Reliability and validity of the study}

Concerning the open-ended items of the research instrument, the coding procedure and development of categories were peer reviewed. The reliability of the Likert type items of the research instrument was verified by the Cronbach's alpha coefficient $(a=0.81)$. The validity was proved by factor analysis (principal component analysis with Varimax rotation), which divided items focused on printed and e-textbooks (see Table 1). The suitability of factor analysis was confirmed by the value of Kaiser-MeyerOlkin (0.87) and Barlett's test of sphericity $\left(X^{2}=1273.98 ; \mathrm{df}=45 ; \mathrm{p}<0.001\right)$. 
Table 1

Results of the factor analysis.

\begin{tabular}{|l|c|c|}
\hline & I. & II. \\
\hline Items focused on printed textbooks & & \\
\hline 1. If we had the e-textbook at school, I would like to use it. & 0.82 & 0.23 \\
\hline 2. Learning with the e-textbook would suit (suits) me. & 0.84 & 0.29 \\
\hline 3. I (would) like videos, audios and animations on the e-textbook. & 0.70 & -0.18 \\
\hline 4. The e-textbook is (would be) more entertaining than the printed textbook. & 0.76 & 0.25 \\
\hline 5. When working with the e-textbook I (would) have bigger interest in the subject. & 0.75 & 0.36 \\
\hline 6. I would like to use the e-textbook as the main learning aid) & 0.79 & 0.43 \\
\hline Items focused on e-textbooks & & \\
\hline 7. Learning with the printed textbook suits me. & 0.22 & 0.63 \\
\hline 8. The printed textbook has more advantages than the e-textbook. & 0.22 & 0.62 \\
\hline 9. The advantage of the printed textbook is its portability. & 0.06 & 0.73 \\
\hline 10. The printed textbook is useless. & 0.37 & 0.62 \\
\hline eigenvalue & 4.83 & 1.30 \\
\hline variance (\%) & 48.26 & 13.00 \\
\hline
\end{tabular}

\section{Results}

Furthermore, we present the results of an analysis that focused on the (preferred) use of e- textbooks in instruction at lower secondary school.

\section{Use of e-textbooks}

$76 \%$ of pupils from the whole sample $(n=250)$ do not use e-textbooks at all, $11 \%$ use them in one subject and $12 \%$ use them in more subjects. More than $75 \%$ would like to use the e-textbook at school ( $25 \%$ rather agree, $52 \%$ agree). Furthermore, it was found out that boys have a closer relationship to technology than girls. More concretely, the majority of both girls and boys would like to use the e-textbook in the future ( $74 \%$ of girls rather agree or agree, $81 \%$ of boys rather agree or agree). 


\section{Pupils' preferences about printed and e-textbooks}

$90 \%$ pupils (would) like videos, audios and animations in e-textbooks (15\% rather agree, $75 \%$ agree). $80 \%$ find the e-textbook more entertaining than the printed textbook ( $19 \%$ rather agree, $61 \%$ agree).

Concerning the printed textbook, pupils were not unanimous in their views. The highest number of pupils (30\%) nor agree/nor disagree that the printed textbook is useless. Similarly the highest number of pupils (36\%) nor agree/nor disagree that the printed textbook suits them.

\section{Comparison of the views of pupils on printed and e-textbooks}

The results of the t-test showed that pupils using only printed textbooks have similar views on printed and e-textbooks as pupils using e-textbooks. Concerning the views on e-textbooks, no significant difference between pupils using printed textbooks and pupils using e-textbooks was found out ( $t=0.97 ; p=0.33$ ), so $H_{01}$ can be accepted. Similar conclusion might be drawn concerning the views on printed textbooks $\left(\mathrm{H}_{02}\right)$, because no significant difference between pupils using printed textbooks and pupils using e-textbook was found out $(t=1.44 ; p=0.15)$. In contrast, the results showed that pupils using only printed textbooks have different views on printed and e-textbooks - a significant difference within the group was discovered and $\mathrm{H}_{03}$ was rejected $(t=11.43 ; p<0.001)$. Similarly pupils using e-textbooks have different views on printed and e-textbooks, $\mathrm{H}_{04}$ is rejected $(\mathrm{t}=6.55 ; \mathrm{p}<0.001)$. Further details are shown in

\section{Figure 1}

Comparing the views of pupils on printed and e-textbooks (group 1: views of pupils using printed textbooks on printed textbooks, group 2: views of pupils using e-textbooks on printed textbooks, group 3: views of pupils using printed textbooks on e-textbooks, group 4: views of pupils using e-textbooks on e-textbooks).

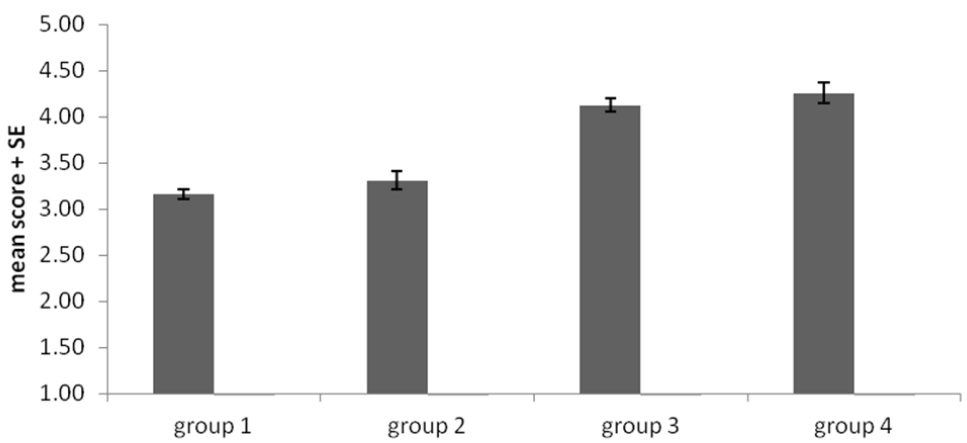


As it is obvious from Figure 1 (group 1 and 2), pupils have rather neutral perception of the printed textbook since the score $2.75-3.25$ is considered neutral. More positive perception of the e-textbook both by pupils who use them and who do not was observed (group 3 and 4).

\section{Advantages and disadvantages of printed and e-textbooks}

The analysis of open-ended items discovered that pupils are aware of advantages and disadvantages of printed and e-textbooks at a rather superficial (material) level. In their statements the occurrence of issues of technical background prevailed. In this aspect, the advantages of printed textbooks were especially portability and independence on electricity, in case of disadvantages, liability to damage and heaviness were considered. In contrast, the advantage of e-textbooks is that in case of tablets all textbooks can be comprised into one device, so the textbook is lighter. On the other hand, pupils mention necessity of an electronic device to read the e-textbook (reader) and its inaccessibility (probably because of the financial dependence on schools). Pupils consider features of printed textbooks which are beneficial for them from the health point of view (not affecting their eyes in comparison with e-textbooks). Concerning issues of learning background they stay at a superficial level. They think that they learn from printed textbooks more easily, but they find e-textbooks more entertaining, interesting and interactive and appreciate learning with multimedia. Regarding disadvantages of e-textbooks they are aware of the fact that e-textbooks can distract their attention from learning (by the access to the Internet). All in all, the analysis of open-ended items showed that pupils assign more advantages to e-textbooks, but they still appreciate, however sometimes contradictorily, several distinctive features of printed textbooks.

\section{Discussion and conclusion}

The presented study pointed out the gap in research of acceptance of e-textbooks by lower secondary school pupils. It discussed the e-textbook term and outlined some aspects of the relevant learning context. It aimed to investigate pupils' perception of the printed and e-textbooks. This aim was specified by three research questions. As a research tool a questionnaire with demographic-context, Likert type and openended items was distributed to lower secondary school pupils using e-textbooks and/ or printed textbooks.

The results of the study showed that no matter if pupils use e-textbooks or not the majority of respondents (both girls and boys) would like to use the e-textbook in the future. What is more, it was discovered that pupils have more positive perception of the e-textbook than the printed textbook. This statement might be influenced by pupils' 
preference of the attractive entertainment function of the e-textbook, especially due to the multimedia it offers, which might be seen as an effect of novelty (see Maynard \& Cheyne, 2005; Oliveira et al.; 2013). However, pupils do not consider the impact of the e-textbook on their learning. Therefore, pupils' superficial responses to the open-ended items showed limits of the questionnaire. Thus further research is necessary to enable a more in-depth view into pupils' preferences of learning with e-textbooks (by means of including more items into the questionnaire, applying the TAM (see chapter 3 ) and conducting interviews with pupils).

Another limit of the study might be seen in the sample. In comparison with studies conducted abroad (e.g. Noor et al., 2012), it was revealed that the majority of respondents do not use e-textbooks at school, even at home. This was caused by the limitation of availability of schools using e-textbooks. The research could be broadened out to involve a larger number of e-textbook users. However, despite the fact that many pupils expressed their views on e-textbooks only based on the offered definition of the term or on their image of the e-textbook, the t-test showed that it had no influence on their views (in comparison with pupils using e-textbooks).

Pupils' rather neutral perception of the printed textbook indicates that pupils are not determined about the future of the printed textbook. They prefer to use e-textbooks at school but do not strictly refuse their printed counterparts. Therefore, a possible solution to the future is to combine both types of textbook and find an appropriate way how to exploit their specific advantages complementing each other.

The limits of the study offer further research in this area. Specifically, further interrogation of pupils is needed. In-depth interviews with pupils are necessary to penetrate through the superficial level of description of advantages and disadvantages of both types of textbooks. Moreover, trial of instruction with e-textbooks in different subjects is essential to gain direct feedback of pupils on the use of e-textbooks. Investigation of teachers' views (about their preferences and experience with e-textbooks) in order to take into consideration a didactical point of view on this issue is welcome as well.

\section{Acknowledgement}

The study was supported by the project MUNI/A/1360/2014 Kurikulum základní školy: metodologické prístupy a empirická zjištění (KUME 2015). 


\section{References}

Armstrong, C. J., Edwards, L., \& Lonsdale, R. (2002). "Virtually there? E-books in UK academic libraries". Program: Electronic Library \& Information Systems, 36(4): 216-27.

Arnold, P., Lilian, L., Thillosen, A., \& Zimmer, G. (2013). Handbuch E-Learning. Lehren und Lernen mit digitalen Medien. Bielefeld: Bertelsmann Verlag.

Beer, W., \& Wagner, A. (2011). Smart Books - Adding context-awareness and interaction to electronic books. In Proceedings of the 9 th international conference on advances in mobile computing and multimedia (pp. 218-222). New York: ACM.

Benbasat, I., \& Barki, H. (2007). Quo vadis, TAM?. Journal of the Association of Information Systems, 8(4): 211-218.

Bennett, L. (2006). E-books: The options: A manual for publishers. London: The Publishers Association.

Borchers O., J. (1999). Electronic books: Definition, genres, interaction design patterns. Conference on Human Factors in Computing Systems. Pittsburgh. [on-line] retrieved from: http://hci. rwth-aachen.de/materials/publications/borchers1999c.pdf

Bradshaw, L. G. (2005). Multimedia Textbooks and Student Learning. MERLOT Journal of Online Learning and Teaching, 1(2). [on-line] retrieved from: http://jolt.merlot.org/documents/Vol1 No2_bradshaw.pdf

Bryant, B., \& Mims, T. (2012). Student's perception of e-texts: Value or hindrance. In SAM International Conference. [on-line] retrieved from: http://www.cob.tamucc.edu/sam/conferences/ SAM2012Papers/Student\%20Perceptions\%20of\%20ETexts\%20Bryant\%20Mims.pdf

Cavanaugh, T. (2002). E-Books and accomodations: Is this the future of print accomodation? TEACHING Exceptional Children, 35(2): 56-61.

Chuttur, M. Y. (2009). Overview of the Technology Acceptance Model: Origins, developments and future directions. Sprouts: Working Papers on Information Systems, 9(37). [on-line] retrieved from: http://sprouts.aisnet.org/9-37.

Cutshall, R. C., Mollick, J. S., \& Bland, E. M. (2009). Use of an e-textbook and web-based homework for an undergraduate business course: students' perceptions. In F. G. Crane (Ed.), Proceedings of- the 10th Annual Conference of the Academy of Business Education. Fort Lauderdale, FL: ABE. [on-line] retrieved from: http://www.abe.sju.edu/proc2009/cutshall.pdf

Elias, E. C., Phillips, D. C., \& Luechtefeld, M. E. (2012). E-books in the classroom: A survey of students and faculty at a school pharmacy. Currents in Pharmacy Teaching and Learning, 4, 262-266.

Falc, E. (2013). An assessment of college students' attitudes towards using an online e-textbook. Interdisciplinary Journal of E-Learning and Learnin Objects, 9. [on-line] retrieved from: http:// mail.volny.cz/download.php?msg_id=0000000014d8002b7dc400046797\&idx=7\&filename= Attitudes2013.pdf\&r=50.23856335084174

Gardiner, E., \& Ronald G. M. (2010). The electronic book. In M. F. Suarez \& H. R. Woudhuysen (Eds.), The Oxford companion to the. Oxford: Oxford UP.

Gay, S. (2007). Epublishing trends in the academic and professional book market. The Official Communication of SPI's Publishing Division, 3(1). [on-line] retrieved from: http://www. spitech.com/ content/37/17/1/Volumes,\%20June\%202007.pdf

Hawkins, D. T. (2000). Electronic books: a major publishing revolution. Online, 24(4): 14-28.

Heejeong Jasmine, L., \& Kok-Lim Alvin, Y. (2015). Addressing the major information technology challanges of electronic textbooks. Journal Of Computer Information Systems, 55(2): 40-47.

Jones, T., \& Brown, C. (2011). Reading engagement: A comparison between e-books and traditional print books in an elementary classroom. International Journal of Instruction, 4(2): 5-22.

Korat, O., Segal-Drori, O., \& Klien, P. (2009). Electronic and printed books with and without adult support as sustaining emergent literacy. Journal of Educational Computing Research, 41(4): 453-475. 
Landoni, M., \& Diaz, P. (2006). E-education: Design and evaluation for teaching and learning. Journal Of Digital Information, 3(4). [on-line] retrieved from: http://journals.tdl.org/ jodi/index.php/ jodi/article/view/118/85.

Liu, T., Lin, Y., \& Pass, F. (2013). Effects of cues and real objects on learning in a mobile device supported environment. British Journal of Educational Technology, 44(3): 386-399.

Mangen, A. (2008). Hypertext fiction reading: Haptics and immersion. Journal of Research in Reading, 31(4): 404-419.

Martinez-Estrada, P. D., \& Conaway, R. N. (2012). E-Books: The next step in educational innovation. Business Communication Quarterly, 75(2): 125-135.

Mayer, R. E. (2005). The Cambridge handbook of multimedia learning. Cambridge: Cambridge University Press.

Mayer, R. E. (2009). Multimedia learning. New York: Cambridge University Press.

Maynard, S., \& Cheyne, E. (2005). Can electronic textbooks help children to learn? The Electronic Library, 23(1): 103-115.

McFall, R., Dershem, H., \& Davis, D. (2006). Experiences using a collaborative electronic textbook: Bringing the Guide on the Side home with you. SIGSE Bulletin, 3(1): 339-343.

McKnight, C., \& Dearnley, J. (2003). Electronic book use in a public library. Journal of Librarianship and Information Science December, 35(4), 235-242.

Miller, B., \& Ranum, D. (2012) Beyond PDF and epub: Toward an interactive textbook. In T. Lapidot, J. Gal-Ezer, M. E. Caspersen, \& O. Hazzan (Eds.), Annual Conference on Innovation and Technology in Computer Science Education, ITiCSE '12 (pp. 150-155). Haifa: ACM.

Mitropoulou, V. (2012). Interactive books for pimary and secondary education for the course of Religion in Greece. In D. G. Sampson, J. M. Spector, D. Ifenthaler, \& P. Isaías (Eds.), IADIS International Conference on Cognition and Exploratory Learning in Digital Age (pp. 269-272). Madrid: IADIS Press.

Nelson, M. R. (2008). E-books in higher education: Nearing the end of the era of hype? EDUCAUSE Review, 43(2): 40-56.

Nicholas, A. J., \& Lewis, J. K. (2010). Learning enhancement or headache: Faculty and e-textbooks. Faculty and Staff - Articles \& Papers, 29. [on-line] retrieved from: http://digitalcommons.salve.edu/ fac_staff_pub/29

Niegemann, H. M., Domagk, S., Hessel, S., Hein, A., Hupfer, M., \& Zobel, A. (2008). Kompendium multimediales Lernen. Berlin, Heidelberg: Springer.

Nogova, M. (2009). Which learning media do students prefer? In J. Rodriguez Rodriguez, M. Horsley, \& S. V. Knudsen (Eds.), 10th International Conference on Textbooks and Educational Media (pp. 557-563). IARTEM: Santiago de Compostela.

Noor, A. M., Embong, A. M. \& Abdullah, M. R. T. L. (2012). E-books in Malaysian primary schools: The Terengganu chapter. World Academy of Science, Engineering and Technology, 66, 298-301.

Minelli-de-Oliveira, J., Camacho-i-Martí, M., \& Gisbert-Cervera, M. (January 01, 2014). Exploring Student and Teacher Perception of E-textbooks in a Primary School.Comunicar, 21, 42, 87-95.

Paas, F., Renkl, A., \& Sweller, J. (2004). Cognitive load theory: instructional implications of the interaction between information structures and cognitive architecture. Instructional Science, 32(1-2): 1-8.

Park, S. Y. (2009). An analysis of the Technology Acceptance Model in understanding university students' behavioral itention to use e-learning. Educational Technology \& Society, 12(3): 150-162.

Reitz, J. (2004). Dictionary for Library and Information Science. Westport, CT: Libraries Unlimited.

Simon, E. J. (2001). Electronic Textbooks: A Pilot Study of Student E-Reading Habits. Future of Print Media Journal. [on-line] retrieved from: http://www.xs4all.nl/ ppintaal/e_documentatie/ e-textbooks-01.pdf. 
Shroff, R. H., Deneen, C. D., \& Ng, E. M. W. (2011). Analysis of the technology acceptance model in examining students' behavioural intention to use an e-portfolio system. Australasian Journal of Educational Technology, 27(4): 600-618.

Staehr, L. J., \& Byrne, G. J. (2011). Improving teaching and learning in an Information Systems subject? A work in progress. The Journal of Issues in Informing Science and Information Technology, 8, 13-23.

Sun, J., Flores, J., \& Tanguma, J. (2012). E-textbooks and students' learning expe riences. Decision Sciences Journal of Innovative Education, 10(1): 63-77.

Sweller, J., Ayres, P., \& Kalyuga, S. (2011). Cognitive load theory. Berlin: Springer.

Terpend, R., Gattiker, T. F., \& Lowe, S. E. (2014). Electronic Textbooks: Antecedents of Students' Adoption and Learning Outcomes. Decision Sciences Journal Of Innovative Education, 12(2), 149-173.

Vassiliou, M., \& Rowley J. (2008). Progressing the definition of "e-book". Library Hi Tech, 26(3), 355-368.

Wang, H. Ch., Chang, Ch. Y. Ch., \& Li, T. Y. (2007). The comparative efficacy of 2D-versus 3D-based media design for influencing spatial visualization skills. Computers in Human Behaviour, 23(4): 1943-1957.

Woody, W. D., Daniel, D. B., Baker, C. A. (2010). E-books or textbooks: Students prefer textbooks. Computers \& Education, 55, 945-948.

Yousafzai, S. Y., Foxall, G. R., \& Pallister, J. G. (2007). Technology acceptance: a metaanalysis of the TAM: Part 1. Journal of Modelling in Management, 2(3), 251-280.

Zurita, G., \& Nussbaum, M. (2007). A conceptual framework based on Activity Theory for mobile CSCL. British Journal of Educational Technology, 38(2), 211-235.

\section{Contact:}

Mgr. Josef Moravec,

Department of Education, Faculty of Education, Masaryk University,

Poříćí 31, Brno, 603 00, Czech Republic;

E-mail: pepamoravec@gmail.com

Mgr. Karolína Pešková, Ph.D., Institute for Research in School Education, Faculty of Education, Masaryk University,

Poříćí 31, Brno, 603 00, Czech Republic;

E-mail: peskova@ped.muni.cz 